\title{
O TRATAMENTO DA CULPABILIDADE ANTES DA FORMAÇÃO DA DOGMÁTICA PENAL E O SURGIMENTO DA PRESUNÇÃO DO CONHECIMENTO DE LEI
}

\section{THE CULPABILITY TREATMENT BEFORE FORMATION DOGMATIC CRIMINAL AND THE EMERGENCE OF THE LAW KNOWLEDGE PRESUMPTION}

\author{
Marco Aurélio Florêncio Filho ${ }^{1}$
}

\section{Resumo}

O presente artigo tem a pretensão de analisar o desenvolvimento histórico da culpabilidade no direito penal, bem como o princípio da presunção do conhecimento de lei. Assim, foi realizada uma abordagem da culpabilidade e da presunção do conhecimento de lei nas sociedades primitivas, na Grécia antiga, no Direito Romano, para, posteriormente, analisar-se a Alta Idade Média e a Baixa Idade Média, para, enfim, analisar referidos institutos no direito germânico.

\section{Abstract}

This article aims to analyse the history development of culpability in the criminal law, as well to analyse principle of law knowledege presumption. Therefore, it was made an approach of culpability and law knowledge presumption in the primitive societies, in ancient Greece, Roman Law for, afterwards, analyse from high to early Middle Age, for, finally, analyse such institutes in the german law.

\section{Palavras-chave}

Culpabilidade penal. Presunção do conhecimento de lei. História do direito penal.

\section{Keyword}

Criminal culpability. Law knowledge presumption. Criminal law history.

\section{INTRODUÇÃO ${ }^{1}$}

O objetivo do presente artigo é analisar a formação e o desenvolvimento da culpabilidade penal, bem como investigar o surgimento do princípio da presunção do conhecimento de lei em matéria penal e os institutos jurídicos a ele relacionados.

A importância do estudo da culpabilidade ganhou especial destaque no direito penal, que, num primeiro momento, tinha como finalidade tão-somente o afastamento da responsabilização objetiva no direito penal, entretanto, com o advento da Modernidade e a estruturação científica do direito penal, em especial, a partir da dogmática penal nascente na Alemanha, a culpabilidade ganhou autonomia na teoria do delito, deixando de ser analisada apenas como exclusão da responsabilidade objetiva

\footnotetext{
${ }^{1}$ Doutor em Direito pela Pontifícia Universidade Católica de São Paulo. Professor da Faculdade de Direito da Universidade Presbiteriana Mackenzie, São Paulo, São Paulo, Brasil.
} 
para ser compreendida, também, como elemento autônomo na estrutura do crime. Ainda, cumpre destacar que, dentro da teoria da pena, a culpabilidade passou a ser concebida como medida e limite para sua aplicação.

É certo que no início do século XIX, houve um aproveitamento do pensamento político vigente - manifesto na exigência da lei prévia, que tinha como escopo fazer com que os cidadãos conhecessem e compreendessem o caráter ilícito da conduta reduzida em um tipo penal,-- para a recepção do princípio da inescusabilidade do desconhecimento de lei, com o objetivo de se organizar o Estado.

Todavia, as distorções trazidas ao direito penal pela aplicação do princípio error ius nocet provocaram um rompimento com a concepção e desenvolvimento do princípio da culpabilidade.

Organizar o Estado a partir do princípio de política legislativa da presunção absoluta do conhecimento de todas as leis penais pelos cidadãos é negar a complexidade social na qual o direito está inserido. Logo, a regra da inescusabilidade do desconhecimento de lei não pode subsistir em um direito penal da culpabilidade, que é um dos pilares do Estado Democrático de Direito.

A regra da presunção do conhecimento da lei em matéria penal no Brasil, regulada na primeira parte do artigo 21, do Código Penal brasileiro, revela-se uma premissa violadora da responsabilidade penal subjetiva, e, consequentemente, do direito penal da culpabilidade.

Buscou-se, assim, neste artigo, investigar o momento histórico do surgimento da premissa da presunção do conhecimento de lei em matéria penal e como se desenvolveu o princípio da culpabilidade nas sociedades ocidentais.

Para tanto, analisamos, inicialmente, a ausência da culpabilidade nos povos primitivos, que desconheceram a responsabilidade penal fundada na culpa e para quem a responsabilidade penal era objetiva e solidária.

Em seguida, foi investigada a culpabilidade entre os povos da antiguidade oriental e entre os gregos. Posteriormente, abordamos o gérmen da culpabilidade entre os romanos. Destacamos a análise da culpabilidade, também, entre os povos da Idade Média, para, enfim, chegarmos ao estudo da culpabilidade no direito germânico.

\section{A ausência da culpabilidade nos povos primitivos: o predomínio da responsabilidade objetiva e solidária}


Nas sociedades primitivas, a aplicação da pena estava associada à violação de um tabu, palavra de origem polinésica que significa a um só tempo o sagrado e o proibido. Nelas, o direito penal estava vinculado ao caráter sacerdotal e teocrático, e " $o$ ilícito se confundia com a quebra da tradição e com a infração ao que a divindade havia proclamado". Isso porque "nas sociedades arcaicas, o direito está fortemente impregnado de religião",2. O antigo direito originou-se, nesse sentido, das crenças religiosas ${ }^{3}$.

O direito era ainda fortemente impregnado pela religião. A distinção entre regra religiosa e regra jurídica é muitas vezes difícil, porque o homem vive constantemente influenciado pelos poderes sobrenaturais. Estas sociedades são caracterizadas pelo que chamamos "indiferenciação", ou seja, as diversas funções sociais que distinguimos nas sociedades modernas, como a religião, a moral e o direito, estão aí confundidas ${ }^{4}$.

Os sacerdotes eram intermediários entre os homens e as divindades, e ao aplicar uma pena evitavam que a ira da divindade recaísse sobre aquele grupo humano, garantindo o bem-estar aos indivíduos que não violaram o tabu. ${ }^{5}$

A culpabilidade não importava para a responsabilização do agente que pertencia a um grupo primitivo. Isto, porque, realizado o fato danoso, o indivíduo era responsabilizado, independentemente da vontade de praticar o evento.

Ainda, a depender do crime, todo o grupo ou clã poderia ser responsabilizado pela ação do agente que o praticou. Verificamos que a responsabilidade, além de ser objetiva, poderia ser também coletiva nas comunidades primitivas. $^{6}$

\footnotetext{
1 WOLKMER, Antonio Carlos. O Direito nas Sociedades Primitivas, p.3. In: WOLKMER, Antonio Carlos. Fundamentos de História do Direito. Belo Horizonte: Del Rey, 2008, p.1-12.

${ }^{2}$ GILISSEN, John. Introdução Histórica ao Direito. Lisboa: Fundação Calouste Gulbenkian, 1986, p. 35.

${ }^{3}$ COULANGES, Fustel de. A cidade antiga. São Paulo: Martins Fontes, 2004, p. 85.

${ }^{4}$ GILISSEN, John. Introdução Histórica ao Direito. Lisboa: Fundação Calouste Gulbenkian, 1986, p. 35.

${ }^{5}$ BRANDÃO, Cláudio. Introdução ao direito penal: análise do sistema penal à luz do princípio da legalidade. Rio de Janeiro: Forense, 2002, p. 14-16. Nas sociedades primitivas, "A destruição do homem é a distribuição simbólica do crime. E tal exigência é tão imperiosa que, desconhecido o verdadeiro agente, vai, muitas vezes, o ato punitivo incidir sobre qualquer outro, a quem seja atribuído o fato pela própria vítima ou seus parentes, ou por processo de natureza mágica. É a responsabilidade flutuante, em busca de um responsável para a pena, que libertará o clã da impureza com que o crime o contaminou." (BRUNO, Aníbal. Direito Penal: parte geral. tomo $1^{\circ}$.Rio de Janeiro, Forense, 1978, p. 69).

${ }^{6}$ AFTALIÓN, Enrique R.; VILANOVA, José. Introduccion al derecho. Buenos Aires: Abeledo-Perrot, 1994, p.1011. Munhoz Netto também observa que nas sociedades primitivas e orientais não houve relevância o estudo da vontade e da consciência de ilicitude, visto que a responsabilização penal do agente era objetiva. Logo, fica prejudicado o estudo da culpabilidade nesses povos. (A ignorância da antijuridicidade em matéria penal. Rio de Janeiro: Forense, 1978, p. 23-24).
} 
Entre os povos primitivos não havia diferenciação funcional, nem distinção entre o ilícito religioso e o penal ${ }^{7}$. O sagrado estava vinculado ao proibido jurídico. Logo, a violação a uma regra penal, moral ou religiosa, resultava sempre a cominação de uma pena.

Nos clãs, a imposição da pena estava associada à preocupação em livrar o grupo da ira da divindade ofendida pelo crime cometido por um dos membros. Segundo destaca von Liszt, a pena primitiva, desde o início do direito penal, tinha um caráter social, resultado do instinto de conservação da comunidade que buscava por meio dela uma reação contra as perturbações sociais. ${ }^{8}$

Essa primeira fase do direito penal passou a ser conhecida como a Fase da Vingança Penal. ${ }^{9}$ Destaca von Liszt que: "La venganza es derecho y deber de la estirpe del muerto o del lesionado y se dirige contra toda la estirpe del lesionado, que se constituye en titular colectivo de la culpabilidad del sangre. ${ }^{, 10}$ Percebemos que a noção de culpabilidade, nessa primeira fase da pena, estava vinculada à ideia de vingança penal.

A segunda forma de pena demonstra de maneira mais evidente o seu caráter social. Essa fase caracteriza-se pela expulsão do indivíduo, que violou determinada norma, da sociedade. Neste período, a pena significava a perda da paz, por parte do indivíduo que violou a conduta proibida.

\footnotetext{
${ }^{7} \mathrm{O}$ direito revela-se o quanto mais moderno a partir da diferenciação funcional, isto é, quando o código de regras que regem um sistema não é influenciado por outro código de regras de outro sistema. No direito penal brasileiro, por exemplo, vê-se claramente que a população carcerária é formada por predominantemente por pobres, o que revela a interferência da economia no direito penal. Segundo Willis Santiago Guerra Filho, "A mencionada autonomia do sistema jurídico não há de ser entendida no sentido de um isolamento deste frente aos demais sistemas sociais, o da moral, religião, economia, política, ciência, etc., funcionalmente diferenciados, em sociedades complexas como as que se tem na atualidade. Essa autonomia significa, na verdade, que o sistema jurídico funciona com um código próprio, sem necessidade de recorrer a critérios fornecidos por algum daqueles outros sistemas, aos quais, no entanto, o sistema jurídico se acopla, através de procedimentos desenvolvidos em seu seio, procedimentos de reprodução jurídica, de natureza legislativa, administrativa, contratual e, principalmente, judicial. (GUERRA FILHO, Willis Santiago. Teoria processual da constituição. São Paulo: RCS, 2007, p. 72). No mesmo sentido, leia-se ADEODATO, João Maurício. Ética e retórica: para uma teoria da dogmática jurídica. São Paulo: Saraiva, 2002, p. 205-206.

${ }^{8}$ LISZT, Franz von La idea del fin en el derecho penal. Granada: Comares, 1995, p. 55.

${ }^{9} \mathrm{O}$ sistema de vingança era estruturado numa tríplice divisão: vingança privada, divina e pública. A vingança privada era caracterizada pela atribuição de uma pena ao indivíduo que violava um tabu. Assim, havia a aplicação da pena com o intuito de evitar uma retaliação divina. Destarte, o povo acreditava que com a cominação de uma pena a ira dos deuses seria amenizada. Com relação à vingança privada, tem-se que a pena, nessa fase, tem um caráter mais pessoal, pois a própria vítima e/ou os seus familiares vingavam-se do autor que realizou o ato proibido. Por fim, a vingança pública se dá a partir do fortalecimento do Estado e a necessidade de se proteger os interesses estatais. Os principais delitos nos quais incidiam as penas públicas eram os de lesa-majestade e, sucessivamente, os que afrontassem a ordem pública, tais como homicídio, lesões corporais, crimes contra a honra e contra a propriedade. SMANIO, Gianpaolo Poggio; FABRETTI, Humberto Barrionuevo. Introdução ao direito penal: criminologia, princípios e cidadania. São Paulo: Atlas, 2010, p. 03-07.

${ }^{10}$ LISZT, Franz von .La idea del fin en el derecho penal. Granada: Comares, 1995, p.55.
} 
Com a transformação das sociedades familiares e das comunidades de paz e a conversão para formação do Estado, originou-se a terceira forma de pena primitiva, denominada pena estatal, que poderia ser exercida pelo chefe militar ou pelo sacerdote com a função de guia da assembleia do povo, de guardião e vingador da paz. Nessa última fase, parece ficar evidente o caráter social da pena, apesar das primeiras formas primitivas de aplicação, conforme demonstrava von Liszt, ter também um caráter social de sanção penal. ${ }^{11}$

Nas comunidades primitivas, no entanto, a pena tinha como marco distintivo responsabilizar sem analisar a culpa. A responsabilidade penal destacava-se então por ser objetiva e solidária.

Daí inferimos que os elementos intelectivo (consciência) e volitivo (vontade) não eram analisados para aferir a culpa do agente e, por consequência, estabelecer sua responsabilidade penal.

\section{A culpabilidade na Antiguidade Oriental e entre os gregos: uma aproximação desses povos a partir da semelhança na forma de responsabilidade penal}

Entre os povos da antiguidade oriental, a culpabilidade também era desconhecida, pois a responsabilidade penal era objetiva e, por vezes, coletiva ${ }^{12}$. Assim como os povos primitivos, aqueles que viviam na região do crescente fértil (egípcios, sumérios e mesopotâmicos) não analisavam a vontade para responsabilizá-los criminalmente.

Temos ainda que entre os povos da antiguidade oriental não havia diferenciação funcional entre os sistemas religioso e jurídico, pois foi atribuído às primeiras reações punitivas dessas comunidades um caráter eminentemente religioso. $\mathrm{O}$

\footnotetext{
${ }^{11}$ LISZT, Franz von .La idea del fin en el derecho penal. Granada: Comares, 1995, p.55-57.

12 A exemplo das penas impostas a toda família pela Lei 117 do Código de Hammurabi: 117. "Se alguém não cumprir a demanda por um débito, e tiver de se vender, ou à sua esposa, seu filho e filha por dinheiro ou tiver de dálos para trabalhos forçados: eles deverão trabalhar por três anos na casa de quem os comprou, ou na casa do proprietário, mas no quarto ano eles deverão ser libertados". O mesmo verifica-se do teor das Leis 209 e 210 : "Se um homem agrediu a filha de um outro homem e a fez expelir o fruto do seu seio, pesará 10 siclos de prata pelo fruto de seu seio. Se essa mulher morreu: matarão a sua filha". (Código de Hammurabi: Código de Manu, excertos [livros oitavo e nono]: Lei das XII Tábuas. Supervisão editorial Jair Lot Vieira. Bauru: Edipro, 2002, p. 22-32). O Código de Hammurabi foi descoberto na Pérsia, em 1901, por um grupo de arqueólogos franceses. Foi promulgado aproximadamente em 1694 a.C., no período do apogeu do império babilônico, pelo rei Hammurabi. (PINTO, Cristiano Paixão Araújo. Direito na Sociedade no Oriente Antigo: Mesopotâmia e Egito, p. 25. In: WOLKMER, Antonio Carlos. Fundamentos de História do Direito. Belo Horizonte: Del Rey, 2008, p. 13-37.
} 
autoritarismo teocrático marcou esse período e a atrocidade das penas foi o caráter distintivo do sistema punitivo daquela época. ${ }^{13}$

Tendo em vista que a lei tinha origem divina para esses povos e o direito também era caracterizado pela ideia de revelação divina ${ }^{14}$, o crime era concebido como uma transgressão ao sagrado, uma ofensa ao divino.

O castigo da pena tinha como finalidade aplacar a cólera dos deuses e, assim, reconquistar a sua benevolência. Os sacrifícios expiatórios revelavam-se verdadeiros rituais de purificação.

$\mathrm{Na}$ antiguidade clássica, cujo período compreende a Grécia, houve um grande avanço no direito. Das grandes contribuições advindas do direito romano, cumpre destacar, segundo Willis Santiago Guerra Filho, que "a questão do caráter científico do Direito romano tem como pano de fundo a teoria da ciência vigente na época, que era grega por excelência."15

A influência grega entre os romanos culminou naquilo que chamamos de cultura helenística, isto é, cultura greco-romana. Logo, o direito romano, como expressão artística que era, foi bastante influenciado pelo pensamento grego.

Uma das maiores dificuldades ao estudo do direito penal grego dá-se pela ausência de fontes seguras sobre o seu sistema punitivo ${ }^{16}$. As informações disponíveis são oriundas dos poetas, oradores, filósofos e, principalmente, trágicos.

É comum atribuir à tragédia grega Antígona de Sófocles, de aproximadamente 441 a.C., como a primeira manifestação propriamente jurídica, um objeto diferenciado dos demais.

O período no qual Antígona foi escrito é conhecido como Direito Natural Clássico, mas destacamos que o Direito Natural não se esgota na antiguidade, tampouco foi tratado de modo uniforme, perpassando, paralelamente, os outros períodos da

\footnotetext{
13 JIMÉNEZ DE ASÚA, Luis. Tratado de derecho penal: concepto del derecho penal y de la criminología, historia y legislación penal comparada. Tomo 1.Buenos Aires: Losada, 1950, p. 267. No mesmo sentido, leia-se Aníbal Bruno (BRUNO, Aníbal. Direito Penal: parte geral. Tomo 1.Rio de Janeiro: Forense, 1978, p. 74)

${ }^{14}$ PINTO, Cristiano Paixão Araújo. Direito na Sociedade no Oriente Antigo: Mesopotâmia e Egito. p.25. In: WOLKMER, Antonio Carlos. Fundamentos de História do Direito. Belo Horizonte: Del Rey, 2008, p. 13-37.

${ }^{15}$ GUERRA FILHO. Willis Santiago; CARNIO, Henrique Garbellini. Teoria da ciência jurídica. São Paulo: Saraiva, 2009, p. 32. Segundo ambos "Aristóteles concebia a ciência como o conhecimento da coisa como ela é, ou seja, o conhecimento de sua necessidade, de suas causas e relações. Assim, naquela época, conhecimento científico era aquele de validez universal e que captava a essência dos fenômenos. Os instrumentos desse conhecimento, como para os positivistas de ontem e hoje, eram a lógica formal e a matemática".

${ }^{16}$ Nesse sentido, BRUNO, Aníbal. Direito Penal: parte geral. Tomo 1. Rio de Janeiro: Forense, 1978, p. 74; e SMANIO, Gianpaolo Poggio; FABRETTI, Humberto Barrionuevo. Introdução ao direito penal: criminologia, princípios e cidadania. São Paulo: Atlas, 2010, p. 13.
} 
História do Direito. Sua característica maior é a existência de uma ordem jurídica supraestatal anterior e superior à norma positivada.

A tragédia Antígona explica bem os postulados do Direito Natural Clássico, pois o rei Creonte havia proibido, sob pena de morte, que o irmão de Antígona, Policines, fosse enterrado segundo a crença grega ${ }^{17}$.

Essa proibição faria com que a alma do irmão de Antígona jamais descansasse; vagando permanentemente pelo limbo, sem conseguir chegar ao Hades. Não obstante à proibição, Antígona enterrou o cadáver de Policines, segundo a tradição, e o rei Creonte condenou-a à morte. Em seu julgamento, Antígona replicou a Creonte, nos seguintes termos:

\begin{abstract}
Não foram, decerto, Zeus nem aquela que tem seu assento entre as divindades protetoras dos mortos, a Justiça, os que promulgaram e prescreveram tais leis aos homens. Eu não creio que teus decretos, escritos pela mão de um mortal, possam ser superiores às leis não escritas e imutáveis dos deuses. Elas não são de hoje nem de ontem, mas são eternas, vigoram em todos os tempos e ninguém sabe quando nasceram. ${ }^{18}$
\end{abstract}

Antígona alegava, pois, a existência de um Direito supraestatal, que era superior ao Direito real (do rei Creonte). Não obstante às alegações de Antígona, o rei Creonte manteve sua decisão e como todo Direito tem uma sanção, o Direito Natural também mostrou a sua, revelada na infelicidade eterna de quem o viola.

Expliquemos: Creonte, um tirano, somente amava duas pessoas na vida, sua mulher e seu filho. Ocorre que o filho de Creonte era apaixonado por Antígona e após a morte desta, suicidou-se. A mulher de Creonte, ante o suicídio do filho, também se suicidou; e este amarga a infelicidade. O desespero de Creonte é descrito na seguinte passagem: “(...) ó filho, sem querer, te matou e a ti também, Eurídice! Ai! Desventurado! Não sei em qual dos dois pousar os olhos, não tenho aonde volver-me. Só me resta em mãos a desgraça. Assim, desabou sobre minha cabeça um destino insuportável. "19 O Coro, grupo de anciãos tebanos, fecha a tragédia dizendo:

\footnotetext{
${ }^{17}$ Destaca Marcelo Alves que: "O edito de Creonte apresenta-se como uma situação - limite em que em nome da cidade, e de seus deuses, não se proíbe só o sepultamento de Polinices no solo de Tebas, mas inclusive que seja lamentado, chorado, e tal interdição não exclui sequer os seus familiares.” (ALVES, Marcelo. Antígona e o direito. Curitiba: Juruá, 2007, p. 62)

${ }^{i 8}$ SÓFOCLES. Antígona. Rio de Janeiro: Difel, 2001, p. 46-47.

${ }^{19}$ SÓFOCLES. Antígona. Rio de Janeiro: Difel, 2001, p. 112.
} 
O fundamento da felicidade sempre foi e será a sensatez. Jamais se deve ser irreverente com os deuses. A empáfia nas palavras acarreta aos soberbos terríveis castigos e, afinal, na velhice, lhes ensina a ser prudentes, moderados e sensatos. ${ }^{20}$

Apesar do grande avanço que os gregos trouxeram à política e ao direito, também não verificamos entre eles o tratamento da culpabilidade. ${ }^{21}$

Os gregos não se valiam, em regra, da análise da intenção do agente para responsabilizar os sujeitos que violassem uma norma penal. Em As Leis ${ }^{22}$, de Platão, verifica-se a punição de animais $^{23} \mathrm{e}$, até mesmo, das coisas, o que demonstra não haver preocupação com a análise da intenção do agente.

É com os romanos, por sua vez, que a intenção do sujeito começa a ter um caráter decisivo para a responsabilidade penal, derivado, certamente do conceito de culpabilidade que surgia.

\section{A culpabilidade no direito romano: desvendando o mito da presunção do conhecimento de lei num direito do caso concreto}

\footnotetext{
${ }^{20}$ SÓFOCLES. Antígona. Rio de Janeiro: Difel, 2001, p. 112. Sobre o assunto, leia-se BRANDÃO, Cláudio. O direito grego clássico. In: BRANDÃO, Cláudio; SALDANHA, Nelson; FREITAS; Ricardo. História do direito e do pensamento jurídico em perspectiva. São Paulo: Atlas, 2012, p. 118-120.

${ }^{21}$ BRANDÃO, Cláudio. Culpabilidade: sua análise na dogmática e no direito penal brasileiro. Revista portuguesa de ciência criminal. Coimbra, Coimbra, Ano 15, n.2, 2005, p.211. Segundo o autor, "(...) a idéia de pessoa humana só existe em função da participação na pólis, não se pode afirmar que os gregos conheceram o conceito de culpabilidade, enquanto juízo de censura sobre a pessoa humana. Com efeito, sequer em gérmen o conceito hodierno de pessoa foi aí aventado."

${ }^{22}$ A obra As Leis desenvolve-se em um diálogo entre "o ateniense" e "Clínias", um estrangeiro. Composta por XII livros, As Leis se ocupa no livro IX exclusivamente de questões relacionadas ao "Direito Criminal". Sobre o assunto, leia-se: GONZAGA, Álvaro de Azevedo; FLORÊNCIO FILHO, Marco Aurélio. O Diálogo entre um filósofo e um jurista - considerações sobre o livro IX - o direito criminal - na obra As Leis de Platão. In: ZOVICO, Marcelo Roland, (Org.). Filosofia do direito: Estudos em Homenagem a Willis Santiago Guerra Filho. São Paulo: Clássica, 2012, p. 32-42.

${ }^{23}$ Segundo Platão, "se uma mula ou qualquer outro animal matar alguém - a não ser que isto ocorra durante alguma competição - o animal será processado pelos parentes do morto por assassinato (...)." (PLATÃO. As leis, ou da legislação e Epinomis. São Paulo: Edipro, 1999, p. 384) Platão faz alusão a uma responsabilização penal diferenciada entre dois grupos: os cidadãos gregos e os estrangeiros e escravos. Os escravos e estrangeiros, por não terem sido educados conforme as leis do Estado, deveriam ter punição mais branda que os cidadãos gregos, por não conhecerem a ilicitude de suas condutas (BRANDÃO, Cláudio. Erro de proibição: uma análise da sua relevância para a exclusão da culpabilidade. Recife: Dissertação de mestrado em direito da UFPE, 1998, p. 73). In casu, a incidência em erro funcionava como uma espécie de atenuante. Cláudio Brandão desenvolve sua linha de raciocínio a partir do seguinte trecho da obra "As Leis" de Platão: “(...) todo aquele que for pego roubando um templo, se for um estrangeiro ou um escravo, terá o estigma de sua maldição marcado a fogo na sua testa e nas suas mãos, além de sofrer o látego no número de golpes decretados pelos juízes; ademais, será expulso nu para além das fronteiras do país, pois talvez após ser assim punido, possa disciplinar-se para uma vida melhor. (...) mas se qualquer cidadão reiteradamente condenado por esse ato, ou seja, a perpetração de alguma falta gravíssima e infame contra os deuses, os pais ou o Estado, o juiz o considerará como já incurável, reconhecendo que, apesar de todo o treinamento e educação que recebeu desde a infância, não se conteve, a ponto de cometer pior das iniqüidades. Para ele a pena será a de morte, o que para os outros [cidadãos] será um exemplo benéfico, pois o verão caído em desgraça e eliminado para além das fronteiras do país." (PLATÃO. As leis, ou da legislação e Epinomis. São Paulo: Edipro, 1999, p. 358-359).
} 
Embora não fossem dados à abstração ${ }^{24}$, foi entre os romanos que surgiu a primeira grande elaboração teórica do direito na qual foram desenvolvidos os institutos jurídicos, todos a partir dos conhecimentos produzidos pelos gregos ${ }^{25}$.

A grande dificuldade ao estudarmos o direito romano é sua longa duração visto que se trata de um produto de uma evolução milenar, que começa com a fundação de Roma (753 a.C.) e se estende até o apogeu do período de Justiniano (553 d.C.) ${ }^{26}$. Segundo Gilissen:

\begin{abstract}
A história do romano é uma história de 22 séculos, do século VII a.C. até ao século VI d.C., no tempo de Justiniano, depois prolongada até ao século XV no império bizantino. No Ocidente, a ciência jurídica romana conheceu um renascimento a partir do século XII; a sua influência permanece considerável sobre todos os sistemas romanistas de direito, mesmo nos nossos dias ${ }^{27}$.
\end{abstract}

Ademais, lembremos que o grande feito do direito romano chegar até nós deve-se ao fato dele ter sido redescoberto. Conforme explica José Reinaldo de Lima Lopes, o direito romano foi verdadeiramente reinventado duas vezes na Europa ocidental: "a primeira vez nos séculos XII a XV e a segunda vez no século XIX, respectivamente pelos juristas da universidade medieval, glosadores e comentadores, $e$ pelos professores alemães que tentavam a unificação jurídica nacional ${ }^{\text {,28 }}$.

Além disso, apesar do caráter religioso do direito punitivo inicial, parece que os romanos foram um dos raros povos antigos que muito cedo libertaram o direito do domínio sacral, distinguindo nitidamente, na doutrina e na prática, o jurídico do religioso $^{29}$.

Certamente, "de todos os povos antigos, foi com os romanos que o direito avançou para uma autonomia diante da religião e da moral. ${ }^{\text {,30. }}$.

\footnotetext{
${ }^{24}$ ALVES, José Carlos Moreira Alves. Direito Romano, vol. I. Rio de Janeiro: Forense, 2004, p. 77.

${ }^{25}$ Nesse sentido, destaca Willis Santiago Guerra Filho que a dinâmica jurídica em Roma é regida pela arte da retórica e pelas técnicas dialéticas herdadas dos gregos (GUERRA FILHO, Willis Santiago.; CARNIO, Henrique Garbellini. Teoria da ciência jurídica. São Paulo: Saraiva, 2009, p. 32)

${ }^{26}$ JIMÉNEZ DE ASÚA, Luis. Tratado de derecho penal: concepto del derecho penal y de la criminología, historia y legislación penal comparada. Buenos Aires: Losada, 1950, tomo I, p. 280. No mesmo sentido, afirma Aníbal Bruno que "Roma nos legou abundante cópia de documentos jurídicos, que nos permitem seguir, com uma informação precisa, a sua longa história, desde a fundação da cidade, ou propriamente desde a Lei das XII Tábuas, até os tempos de Justiniano, na decadência do Império." (BRUNO, Aníbal. Direito Penal: parte geral. Tomo 1.Rio de Janeiro: Forense, 1978, p.79)

${ }^{27}$ GILISSEN, John. Introdução Histórica ao Direito. Lisboa: Fundação Calouste Gulbenkian, 1986, p.80.

${ }^{28}$ LOPES, José Reinaldo de Lima. O Direito na História. São Paulo: Atlas, 2008, p.16.

${ }^{29}$ BRUNO, Aníbal. Direito penal: parte geral. Tomo 1.Rio de Janeiro, Forense, 1978, p. 79-80.

30 WOLKMER, Antonio Carlos. O Direito nas Sociedades Primitivas, p.5. In: WOLKMER, Antonio Carlos. Fundamentos de História do Direito. Belo Horizonte: Del Rey, 2008, p.5.
} 
São inúmeras as contribuições ao direito, especialmente o direito penal, advindas dos romanos. Entre eles, citemos o desenvolvimento da doutrina da imputabilidade, da culpabilidade e suas excludentes.

Também os romanos desenvolveram institutos como o do nexo de causalidade, dolo, imprudência, caso fortuito. Cumpre destacar que foram também os primeiros a abordar a doutrina do erro por meio da dicotomia error facti-error ius cujo legado foi a ideia de dolus malus, indispensável para a análise do erro em direito penal, nesse período histórico. ${ }^{31}$

Imprescindível para entendermos a formação da culpabilidade entre os romanos é o estudo do dolus malus. Sobre o tema, afirma Lucio Herrera que "los romanos fueron los primeros en tratar cientificamente la cuestión de la intención. „32

A unidade da culpabilidade (intenção atrelada ao mau propósito, ou dolus malus) é superada pelos romanos ao descobrirem sua segunda forma, qual seja, a culpa stricto sensu. Assim, havia o dolus malus e a imprudência entre os romanos.

Destaca Binding, por sua vez, que a Lex Duodecimum Tabularum ${ }^{33}$ não contemplava a imprudência, que só veio a ser tratada na interpretatio da Lex Aquilia, cuja origem é desconhecida ${ }^{34}$.

Segundo Binding, o tratamento da imprudência inicialmente não estava ao lado do dolo, mas sim do caso fortuito, do Ungefährwerk. ${ }^{35}$

Para os romanos a imprudência nunca se converteu em culpabilidade delitiva. Segundo Binding, os imperadores romanos proclamaram a impunidade dos agentes que praticavam um homicídio imprudente. ${ }^{36}$

A Lei das Doze Tábuas dispunha que ao agir sem intenção, incidiria sobre o sujeito uma expiação religiosa, mas não uma pena. As leis penais ulteriores tomaram

\footnotetext{
${ }^{31}$ PRADO, Luiz Regis. Curso de direito penal brasileiro: parte geral. São Paulo: RT, 2000, p. 37-38.

${ }^{32}$ HERRERA, Lucio Eduardo. El error en materia penal. Buenos Aires: Abeledo-Perrot, 1971, p. 14.

33 A Lei das Doze Tábuas trouxe um tratamento diferente das legislações anteriores, no que se refere ao atuar do agente sem a intenção de praticar determinada conduta. Segundo a tradição, sobre a qual, contudo, em relação a certos particulares apresenta algumas variantes, a Lei das Doze Tábuas é considerada como uma obra que forma um quid unicum na história do direito romano, cujo cenário era de uma profunda crise entre os patrícios e plebeus, sendo que em 451 a.C., sob a direção de Appio Cláudio, foi nomeado o decemviri, cuja comissão redigiu dez tábuas, em bronze, de lei, às quais, no ano seguinte, foram acrescentadas mais duas, e publicadas pelos cônsules Valério e Orazio, e a este monumento legislativo os romanos exaltaram como fons omnis pubilici privatique iuris. (GROSSO, Giuseppe. Lezioni di storia del diritto romano. Torino: G. Giappichelli, 1965, p. 93-95) Informa-nos José Carlos Moreira Alves que "Um dos objetivos dos plebeus era o de acabar com a incerteza do direito por meio da elaboração de um código, o que viria a refrear o arbítrio dos magistrados dos patrícios contra a plebe." (ALVES, José Carlos Moreira. Direito romano. Rio de Janeiro: Forense, 2004, p.24)

${ }^{34}$ Segundo BURDESE, porém, a lex Aquilia é de plebiscito não anterior a 286 a.C. (BURDESE, Alberto. Manuale di Diritto Privato Romano. Torino: Unione Tipografica Editrice Torinese (UTET), 2003, p. 529.

${ }^{35}$ BINDING, Karl. La culpabilidad en derecho penal. Montevideo-Buenos Aires: BdeF, 2009, p.14.

${ }^{36}$ BINDING, Karl. La culpabilidad en derecho penal. Montevideo-Buenos Aires: BdeF, 2009, p.16.
} 
por base a vontade antijurídica do agente, isto é, pressupunha-se que o autor conhecesse a ilicitude de sua conduta para ser responsabilizado criminalmente.

Caso não fosse verificada a vontade antijurídica do autor, o erro de fato excluía a punibilidade. A vontade delituosa que se aplicava a todo o campo do direito era designada pela palavra dolus reforçada pelo adjetivo mala, astucia mala, dolus malus, que significava a vontade exercida com a consciência de injustiça. ${ }^{37}$

Assim, temos que era parte integrante da culpabilidade a consciência de antijuridicidade. ${ }^{38}$ Todavia, a vontade antijurídica (dolus malus) pressupunha, ainda, a necessidade de saber que o fato praticado era contrário à lei, pois se assim não ocorresse, era afastada do agente a responsabilidade pelo erro de fato. ${ }^{39}$

A doutrina não diverge quanto à escusabilidade do erro de fato. No entanto, a escusabilidade para o desconhecimento da lei por meio da incidência do erro de direito é um assunto controvertido.

Para Binding, as fontes estudadas mencionam frequentemente que $\mathrm{o}$ acusado invocava sempre a sua ignorantia legis e teria agido em imprudens iuris. A discussão trazida por Binding é de natureza processual tendo em vista sua natureza probatória. Não se presumia, entre os romanos, iuris et de iure, o conhecimento da lei, visto que o magistrado quando verificava no caso concreto, que o agente desconhecia a lei, libertava o sujeito. ${ }^{40}$

No direito romano, o desconhecimento de lei não era considerado na formação da culpabilidade do agente, mas na análise probatória do caso concreto, até porque os romanos analisavam o direito a partir do caso concreto.

A confusão mencionada por Binding sobre a presunção do conhecimento de lei tem fundamento em várias obras nas quais a lógica sempre é a mesma, ou seja, a vida em sociedade obriga a todos conhecerem as leis do Estado. ${ }^{41}$

\footnotetext{
${ }^{37}$ MOMMSEN, Teodoro. Derecho penal romano. Bogotá: Editorial Temis S.A., 1999, p. 60-61.

${ }^{38}$ BINDING, Karl. La culpabilidad en derecho penal. Montevideo-Buenos Aires: BdeF, 2009, p. 15.

${ }^{39}$ MOMMSEN, Teodoro. Derecho penal romano. Bogotá: Editorial Temis S.A., 1999, p. 60.

40 "Las fuentes mencionan con cierta frecuencia que el acusado invocaba su ignorantia legis, o que en ese caso habría sido imprudens iuris. No establecieron reglas especiales para el tratamiento de la invocación de tal "error de Derecho". No hay trazas de que existiera una presunción jurídica, ni mucho menos una praesumtio iuris et de iure, de conocimiento de la norma. Quien invocaba el error debía intentar convencer de su credibilidad al juez; si lo lograba, quedaba libre. En lo que alcanzamos a ver, los romanos procedían con prudencia al valorar esta alegación, pero sin posición alguna." (BINDING, Karl. La culpabilidad en derecho penal. Montevideo-Buenos Aires: BdeF, 2009, p. 73). Para Binding, norma é a proposição jurídica geradora de um dever. (BINDING, Karl. La culpabilidad en derecho penal. Montevideo-Buenos Aires: BdeF, 2009, p. 73.). Apenas pode existir um dever para um agente, se esse sujeito conhecê-lo.

${ }^{41}$ Sobre o direito romano, afirma Fábio Machado que: “(...) para que a lei penal fosse aplicada, prescindia-se que o agente tivesse conhecimento da mesma, abrindo-se oportunidade para a realização de presunções jurídicas de conhecimento da lei, posto que o homem que vive em sociedade estava obrigado a conhecer as leis do Estado e,
} 
No entanto, Binding é categórico ao afirmar que em momento algum, nas fontes que tratam do direito romano, é mencionado que as regras error iuris nocet e error facti non nocet pretendiam estabelecer uma presunção de prova. ${ }^{42}$

Pascoale Voci, por sua vez, sintetiza as correntes que abordam o erro de direito, afastando-se da teoria formulada por Binding:

Das três possíveis teorias, relevância do erro de direito, sua irrelevância, media sententia, todas as três foram sustentadas com acureza e empenho. A exegese permite dizer que nem a primeira nem a segunda são justificadas pelas decisões das Fontes. Não a primeira, de Binding, que então não se explicariam os textos no qual à ignorantia iuris não vem atribuída qualquer eficácia discriminante: a partir da in ius vocatio do patrono ao incesto se tem uma gama de hipóteses não elimináveis por qualquer dispositivo crítico. E de outra parte, a segunda tem o equívoco de ter sido derivada a partir dos textos que ou não se relacionam diretamente com o direito penal ou comtemplam casos excepcionais. A terceira teoria é para mim aquela que mais se aproxima à verdade: o fundamento exegético foi agora examinado. Mas sobretudo essa permite reunir sob um ponto de vista comum as mais variadas hipóteses das Fontes. Trata-se de um ato ilícito previsto pelo direito penal privado ou pelo público, pelo direito pretoriano ou por um estatuto municipal, a resposta é sempre a mesma: o erro de direito exclui o dolo quando incide sobre uma norma cuja origem positiva é evidente. Aqui o dolo poderia ser dado pela consciência da violação que a obrigação de respeitar as leis é já uma exigência da moral. Não é de admitir-se que os romanos tenham estabelecido um tratamento disforme da ignorância de direito nos atos ilícitos, de cujo pressuposto é o dolo, porque do dolo não podiam ter senão um conceito: e dessa observação não pode haver razão que se limita a estudar apenas determinadas categorias de ilícitos" 43

\footnotetext{
portanto, qualquer violação em que incorresse pressupunha-se o conhecimento de sua ilicitude." (MACHADO, Fábio Guedes de Paula. A culpabilidade no direito penal contemporâneo. São Paulo: Quartier Latin, 2010, p.34).

${ }^{42}$ BINDING, Karl. La culpabilidad en derecho penal. Montevideo-Buenos Aires: BdeF, 2009, p. 75.

${ }^{43}$ Tradução livre de: "Delle tre possibili teorie, rilevanza dell'error iurus, sua irrilevanza, media sententia, tutte'e tre sono state sostenute con acutezza ed impegno. L'esegesi permette di dire che nè la prima nè la seconda sono giustificate dalle decisioni delle Fonti. Non la prima, del Binding, chè allora non si spiegherebbero i testi ove all'ignorantia iuris non viene attribuita alcuna eficácia discriminante: dalla in ius vocatio del patrono all'incesto s'ha una gamma d'ipotesi non eliminabili da alcun accorgimento critico. E, d'altra parte, la seconda há il torto di essere ricavata da testi che o non riguardano diretamente il diritto penale o contemplano casi eccezionali. La terza teoria è per me quella che si avvicina di più ala verità: il fondamento exegético ne è stato esaminato ora. Ma sopratutto essa permette di riunire sotto un punto di vista comune le svariatissime ipotesi dele Fonti. Si tratti di un atto illecito previsto dal diritto penale privato o dal pubblico, dal diritto pretório o da uno statuto municipale, la risposta è sempre la medesima: l'error di diritto esclude il dolo quando cada su di uma norma la cui origine positiva è evidente. Qui il dolo potrebbe essere dato dalla coscienza dela violazione, chè l'obbligo di rispettare le leggi è già un'esigenza dela morale. Non è da ammettersi che i Romani abbiano stabilito un diforme tratamento dell'ignorantia iuris negli atti illeciti, di cui pressuposto è il dolo, perchè del dolo non potevano avere se non un concetto: e di questa osservazione non può aver ragione chi si limita a studiare solo date categorie di illeciti." (VOCI, Paquale. L'errore nel direito romano. Milano: Dott. A. Giuffré, 1937, p. 209). Certo é que "Brechas, no error juris nocet, vêm-se abrindo, desdes antigas legislações. No direito romano, escusável era o êrro de direito, quando cometido por mulheres, menores, soldados e camponeses. Na média-idade, o êrro, sôbre direito local, considerava-se relevante. Sente-se, modernamente, a tendência, que cresce em legislações cultas, para não distinguir, quanto à relevância jurídico-penal, entre êrro de fato e de direito." (LUNA, Everardo da Cunha. Estrutura jurídica do crime e outros estudos. Recife: Unversidade Federal de Pernambuco, 1970. p. 266)
} 
Para entendermos a relação entre culpabilidade e erro é imprescindível delimitar a estruturação dicotômica do erro (error facti-error ius) para posteriormente estabelecermos o caráter de escusabilidade ou não do erro de direito.

Destacamos desde agora que o erro e a culpabilidade são assuntos vinculados intrinsecamente, pois sendo o erro a falsa compreensão sobre um objeto ${ }^{44}$, macula diretamente a intenção do indivíduo que pratica uma conduta desconhecendo, ou compreendendo mal, o que praticava.

As duas espécies de erro distinguiam-se pelo fato de que o erro de fato se referia às condições materiais exigidas para a aplicação de uma regra de direito, enquanto o erro de direito versava sobre o direito objetivo. ${ }^{45}$ Segundo Mommsen,

\begin{abstract}
El concepto de delito requiere la existencia de una voluntad contraria a la ley en la persona capaz de obrar. Este principio fundamental del derecho penal ya desarrollado fue desconocido en el derecho penal de los primeros tiempos; entonces se cuestionaba sobre el hecho en sí, antes que sobre el estado de alma en que el mismo tenía su base. El sacrificio humano se le impone al criminal de la propia manera que al monstruo el que mira las desnudeces de una virgen consagrada a Vesta debe morir; la muerte dada a un hombre origina una deuda que debe ser reparada, haya tenido el autor intención de causarla o no la haya tenido. Esta antigua concepción no había desaparecido todavía completamente en el momento en que comienzan nuestras noticias históricas, o sea en el código de las Doce Tablas, pero estaba muy en decadencia. ${ }^{46}$
\end{abstract}

Em regra, a ignorância e a falsa compreensão sobre um fato sempre excluíam a responsabilidade criminal do agente. Quem ofendia um magistrado, por exemplo, sem saber que o ofendido era magistrado, não cometia crime de majestade; a relação sexual entre duas pessoas que desconhecem seu parentesco também não era incesto; e ainda, lesionar um homem a quem se tinha por escravo não era um crime de injúria. $^{47}$

O problema da ausência de responsabilidade penal da dicotomia do erro está no erro de direito, pois diferentemente do tratamento dado ao error facti, a maior parte

\footnotetext{
${ }^{44}$ Segundo Jimenez de Aúsa, "En el área de la psicología hay una distinción fundamental entre a ignorancia y el error, que se halla ya en Platón. La primera supone la falta absoluta de toda representación y consiste en una entera ausencia de noción sobre un objeto determinado; es un sentido negativo. El error supone una idea falsa, una representación errónea de un objeto cierto; es un estado positivo" (JIMÉNEZ DE ASÚA, Luis. La ley e el delito: curso de dogmática penal. Caracas: Adreas Bello, 1945, p. 490-491).

${ }^{45}$ HERRERA, Lucio Eduardo. El error en materia penal. Buenos Aires: Abeledo-Perrot, 1971, p.14.

${ }^{46}$ MOMMSEN, Teodoro. Derecho penal romano. Bogotá: Temis S.A., 1999, p.60.

${ }^{47}$ MOMMSEN. Teodoro. Derecho penal romano. Bogotá: Temis S.A., 1999, p. 60-61.
} 
das referências consultadas denotam que, em regra, o desconhecimento da lei não afastava a culpabilidade do agente $e^{48}$.

Quanto à ignorância da lei, foi aplicada ao direito penal romano uma regra de direito privado: a presunção do conhecimento das leis do Estado por todos os indivíduos. ${ }^{49}$ Logo, em Roma, vigorou o princípio error jus nocet. Entretanto destacamos que o princípio error jus nocet não era absoluto, ou seja, admitia exceção. Conforme Mommsen,

El derecho romano aplicó a la ley penal que por ignorancia había sido violada, una regla del derecho privado, según la cual, el hombre que vivía en medio de tráfico de mundo estaba obligado a conocer las leyes del Estado, y por tanto, cualquier violación legal que practicase, aun no siendo consciente y querida, implicaba culpabilidad, mientras que, por el contrario, las mujeres y los rústicos estaban dispensados de esta obligación, y por consiguiente, cuando dichas personas cometían una falta contra una leu penal que estuviese desprovista de fundamento moral, se presumía que no había conocido tal ley, y por lo mismo quedaban exentos de culpa. ${ }^{50}$

Toda a sistematização empreendida atualmente pelos estudiosos sobre o direito romano é fruto do pensamento da modernidade, tendo em vista que os romanos aplicaram o direito por meio da retórica e da dialética e não a partir de conceitos ou classificações abstratas.

Assim, temos que a aplicação e o estudo dos institutos jurídicos aconteceram a partir de fatos cotidianos, pois os romanos não cuidaram da doutrina sistemática dos conceitos fundamentais dos institutos jurídicos ${ }^{51}$.

Nesse sentido, os estudos desenvolvidos por Binding sobre o princípio error iuris nocet demonstram que não foi retirado, no direito romano, o direito do indivíduo de alegar o desconhecimento da lei.

\footnotetext{
48 Para Trapero Barreales: "La primera teoría desarrollada en relación con el tratamiento del error en general está unida a la distinción entre el error de hecho y el error de Derecho así como el principio de la ignorancia de la ley no excusa o el 'error iuris nocet'. Esta primera explicación hunde sus raíces en el Derecho romano y se impone en las siguientes etapas históricas hasta el desarrollo de la teoría del delito en la segunda mitad del siglo XIX." (TRAPERO BARREALES, María A. El error en las causas de justificación. Valencia: Tirant lo Blanch, 2004, p. 48)

${ }^{49}$ Segundo Caetano Duarte, "para os romanos, e de acordo com a fórmula de Paulo - regula est juris quidem ignorantiam cuique nocere, facti vero ignorantiam non nocere - existia a presunção de que todos cumpriam a obrigação de conhecer a lei, isto para justificar a irrelevância do erro de direito. Este era indesculpável, pelo menos num homem instruído ou que tivesse a faculdade de se instruir." (DUARTE, Caetano. O erro no código penal. Lisboa: Veja, 1984, p. 19-20). A regra de que o erro de direito era indesculpável comportava exceção, desde que a norma não fosse de direito natural, pois esta é inerente a própria natureza humana, e desta feita é sempre indesculpável.

${ }^{50}$ MOMMSEN. Teodoro. Derecho penal romano. Bogotá: Temis S.A., 1999, p. 64-65.

${ }^{51}$ BRUNO, Aníbal. Direito penal: parte geral. tomo 1.Rio de Janeiro, Forense, 1978, p. 82.
} 
Uma má interpretação do erro de direito sob o prisma da estabilidade, provavelmente levou os autores modernos (positivistas), ao recepcionarem a dicotomia error facti-error ius, atribuírem ao erro de direito o seu caráter inescusável.

Decerto, o direito romano era um direito do caso concreto um saber prático no qual a conjunção de diversos fatores permitia ao pretor retirar do caso concreto a decisão mais justa. Para Guerra Filho e Carnio,

A conjunção desses fatores autoriza-nos a considerar científico o estudo do Direito já em Roma, desde que se tenha uma concepção ampla do que seja ciência, enquadrando-a em uma perspectiva histórica, como se faz a moderna epistemologia não positivista. Tratava-se de um saber prático, guiado por um método próprio, adequando a seu objeto, dotado de um senso de rigor na construção de sua terminologia e mesmo de uma intuição para atingir a veracidade por intermédio da retórica." 52

Logo, difícil imaginar entre os romanos uma regra que não comportasse exceções. Nas lições de Celso, o direito era a arte do bom e do equitativo, ius est ars boni et aequi ${ }^{53}$. O pretor, em cada caso, extraía a melhor decisão do caso concreto. $\mathrm{O}$ direito romano foi, sobretudo, um direito costumeiro, pois a lei existia como um guia, um norte que, inclusive, o prudente arbítrio do julgador poderia afastar, para alcançar a decisão mais justa possível. ${ }^{54}$

Logo, concordamos com Binding quanto ao fato das regras error iuris nocet e error facti non nocet pretenderem estabelecer uma presunção de prova, que comportava exclusões. Não poderia haver uma presunção absoluta a partir da aplicação do direito no caso concreto. Segundo Jorge de Figueiredo Dias,

\footnotetext{
52 GUERRA FILHO. Willis Santiago; CARNIO, Henrique Garbellini. Teoria da ciência jurídica. São Paulo: Saraiva, 2009, p.33.

${ }^{53}$ A definição de ius atribuída a Celso encontra-se no fragmento do Digesto 1, 1, 1, pr.: Ulpianus libro primo institutionum. Iuri operam daturum prius nosse oportet, unde nomen iuris descendat. est autem a iustitia appellantum: nam, ut eleganter Celsus definit, ius est ars boni et aequi. ULPIANO; Instituciones, libro I.- Conviene que el que haya de estudiar el derecho, conozca primero de dónde viene la palabra ius (derecho). Llámase así de iustitia (justicia); porque, según lo define elegantemente Celso, es el arte de lo bueno y equitativo. (Corpus Iuris Civilis, Cuerpo del Derecho Civil Romano, traduzido do original alemão publicado por KRIEGEL, HERMANN e OSENBRÜGGEN, ao espanhol por D. Ildefonso L. García del Corral. Barcelona: Jaime Molinas, 1889, p. 197).

54 "Porque a lei é a principal fonte do direito, nos dias atuais, poderíamos ser susceptíveis de acreditar que a principal fonte do direito romano era a lei, o que seria uma grave incorreção. A própria definição romana de direito exposta, inclusive, afasta-nos da primazia da lei como fonte do Direito. Pois bem, no digesto, a definição de direito dada por Celso é esclarecedora: o direito é a arte do bom e do equitativo (jus est ars boni et aequi). O direito é comparado à arte e o pretor, que era o juiz romano, ao artesão: assim como o artista constrói a peça de arte, cabe ao pretor construir, no caso concreto, a decisão boa e justa. O direito é uma arte porque se extrai do caso a solução que concretiza a justiça na situação concreta, é essa a boa decisão. Na ideia romana de direito, a solução para a lide borá do caso, não de uma norma geral e prévia, que se assemelha a uma caminho predeterminado que deve ser seguido pelo pretor. Destarte, o direito romano não coloca a lei como fonte principal do direito, mas ela servirá como um esquema de interpretação, que pode ser afastado através do arbítrio do pretor, sempre que sua solução não conduzir a uma decisão boa e justa.” (BRANDÃO, Cláudio. O direito no pensamento romano. In: BRANDÃO, Cláudio; SALDANHA, Nelson; FREITAS; Ricardo. História do direito e do pensamento jurídico em perspectiva. São Paulo: Atlas, 2012, p. 125-126)
} 
(...) em face destes 'dados' do pensamento jurídico-penal romano, quisermos alcançar (de acordo com o princípio, também de Paulo - D. 50, 17, 1 -, 'non ex regula ius sumatur, sed ex iure, quod est, regula fit') um justo entendimento da regra da irrelevância do erro iuris, notaremos que, sem atropelar o seu teor literal e longe, por conseguinte, da interpretação de Binding, se alcança para ela um sentido e um fundamento abissalmente diferentes dos tradicionais. Um sentido e um fundamento tais que permitem compreender, ao mesmo tempo, as excepções que assinalámos e sem o que estaria a imputar-se aos juristas romanos uma técnica conceitualista-formal e um apego (como hoje diríamos) a uma 'jurisprudência dos conceitos' que lhes eram de todo estranhos. ${ }^{55}$

A leitura dos doutrinadores positivistas do erro de direito entre os romanos pode ter levado às interpretações equivocadas mencionadas por Karl Binding. ${ }^{56}$

\section{A culpabilidade na Idade Média: avanços sobre a escusabilidade do princípio error ius nocet}

O direito medieval ocidental é marcado por um vasto período e diferentes enfoques. É possível, por sua vez, fazermos um corte epistemológico e estruturarmos a Idade Média em dois grandes períodos: a Alta Idade Média, marcada pelo feudalismo, e a Baixa Idade Média, que compreende o poder temporal da Igreja. ${ }^{57}$

A Alta Idade Média ${ }^{58}$ compreende o período que começa com a tomada de Roma por Odoacro (476 d.C) até o ano 1000, quando ocorre na Europa Ocidental um renascimento da cultura jurídica dentro das universidades. Segundo Lopes, “desde os

\footnotetext{
${ }^{55}$ DIAS, Jorge de Figueiredo. O problema da consciência da ilicitude em direito penal. Coimbra: Coimbra, 2000, p.34-35.

${ }_{56}$ Ainda, tem-se com Jorge de Figueiredo Dias: “(...) seja qual for a relativa pobreza dos textos que até nós chegaram sobre o ponto em análise e a extensão das interpolações que sofreram, há hoje duas conclusões cuja exactidão é reconhecida pela doutrina mais qualificada e que apontavam para uma compreensão da regra pauliana completamente diferente do entendimento tradicional. A primeira é a da existência de indubitáveis 'exepções' ao princípio da irrelevância do error iuris, aceites (embora em diferente medida) tanto pelo direito clássico como pelo pós-clássico, a favor dos soldados, dos rústicos, das mulheres e das crianças. Existência em absoluto incomprensível quando se considerasse, à luz do entendimento tradicional, ser a espécie 'jurídica' do erro que dá fundamento ao princípio da irrelevância e dever este afirmar-se quaisquer que fosses os motivos do erro e a culpa do agente na actuação; pois não se concebe que a profissão do soldado, a simplicitas do rústico, a infirmitas sexus da mulher ou a incapacidada da criança pudessem transformar em erro de facto aquilo que em si seria um erro de direito! E a esta acresce uma segunda conclusão: a de que o direito penal romano, diferenciando nitidamente os 'crimina naturaliter proba' (aqueles que tinham um fundamento 'natural' evidente) dos crimes de 'mera criação política' (derivados de necessidades oportunísticas de organização da 'polis'), só relativamente aos primeiros fazia valer o princípio da irrelevância do error iuris, mas já não, em regra, relativamente aos segundos, mesmo em direito justinianeu. E também aqui ninguém deixará, por certo, de convir que a espécie 'natural' ou 'legal' da incriminação não é susceptível de alterar a espécie 'jurídica' do erro em que o agente tenha incorrido, por forma a deixar intocada a validade da dicotomia em análise!" (DIAS, Jorge de Figueiredo. O problema da consciência da ilicitude em direito penal. Coimbra: Coimbra, 2000, p. 33-34)

${ }^{57}$ BRANDÃO, Cláudio. Direito no pensamento jurídico medieval. In: BRANDÃO, Cláudio; SALDANHA, Nelson; FREITAS; Ricardo. História do direito e do pensamento jurídico em perspectiva. São Paulo: Atlas, 2012, p. 134.

${ }^{58}$ Vale mencionar que o substantivo Alt, em alemão, significa velho, deste modo, a Alta Idade Média é a velha Idade Média. (BRANDÃO, Cláudio. Direito no pensamento jurídico medieval. In: BRANDÃO, Cláudio; SALDANHA, Nelson; FREITAS; Ricardo. História do direito e do pensamento jurídico em perspectiva. São Paulo: Atlas, 2012, p.135).
} 
séculos XI e XII assiste-se a uma diferenciação funcional do direito, como não se vira entre os séculos VI e X." 59

Havia um alto índice de analfabetismo, até mesmo entre os nobres. Segundo aponta John Gilissen, "aliás, à parte de alguns clérigos, ninguém sabe ler nem escrever." 60 .

Somente foi conservada a cultura escrita e a herança da civilização helenística em razão de religiosos da igreja católica, em geral, letrados. Destacamos neste contexto a grande contribuição dos monges beneditinos, sobretudo os copistas.

Após a queda do Império Romano houve uma desconcentração do poder. Não existia uma organização estatal complexa entre os bárbaros que garantisse a estabilidade e a centralização de poder. Foi um período caracterizado por uma intensa crise social, econômica e política ${ }^{61}$.

É ao longo da Idade Média que verificamos uma fusão entre os costumes germânicos e as instituições romanas ${ }^{62}$.

Justamente nesse vazio surgiu o direito vulgar, que reverbera em uma situação plural de direitos. Segundo José Reinaldo de Lima Lopes, com os reinos bárbaros houve uma progressiva pessoalidade das leis, de maneira que elas eram aplicadas conforme a etnia. Acrescenta o autor:

\begin{abstract}
Durante muito tempo, ao longo de toda a Idade Media, invocam-se as leis pessoais. Em Módena, em pleno século XII os residentes se dizem romana lege viventes em oposição aos núcleos de franceses que se dizem sálica lege viventes. De modo que, com todo o desenvolvimento do direito medieval, sobreviverá durante séculos a noção da possibilidade da existência simultânea, no mesmo território, de ordens jurídicas paralelas, aplicáveis a grupos de pessoas distintas ${ }^{63}$.
\end{abstract}

A produção do direito, durante a Alta Idade Média, é pouquíssima quando comparada ao direito romano. Temos notícias de raras coleções de leis dessa época,

\footnotetext{
${ }^{59}$ LOPES, José Reinaldo de Lima. O Direito na História. São Paulo: Atlas, 2008, p.49.

${ }^{60}$ GILISSEN, John. Introdução Histórica ao Direito. Lisboa: Fundação Calouste Gulbenkian, 1986, p. 191.

${ }^{61}$ Há o declínio das conquistas territoriais, crise na mão de obra, corrupção nos costumes, ruralização da economia, declínio das atividades comerciais, conflitos com as províncias, diminuição da arrecadação de impostos e diminuição da produção agrícola.

${ }^{62}$ LOPES, José Reinaldo de Lima. O Direito na História. São Paulo: Atlas, 2008, p.51. Segundo o autor, não ocorre, porém, de pronto uma fusão de romanos e bárbaros. "Vivem lado a lado e sem se misturar".

${ }^{63}$ LOPES, José Reinaldo de Lima. O Direito na História. São Paulo: Atlas, 2008, p.51. E acrescenta o mesmo autor: "Assim, no mesmo espaço do reino dos francos sobrevivem comunidades de galo-romanos. A eles se aplica o direito romano, seu direito. Aos francos se aplicava o direito franco, seus costumes, sua tradição. Sobreviverá durante séculos a noção da possibilidade da existência simultânea, no mesmo território, de ordens jurídicas paralelas, aplicáveis a grupos de pessoas distintas. Na "Reconquista" da Península Ibérica aos mouros, Toledo (tomada em 1085) será sede um reino de três religiões (cristiansmo, judaísmo e islamismo), com o isolamento jurídico de três comunidades (proibição de casamentos mixta religione) ainda que possibilitados os contatos meramente civis”.
} 
dentre elas a Lex Burgundiorum (anterior a 500 d.C.), a Lex Romana Visigothorum, chamada também de Breviário de Alarico (506 d.C)., e a Lex Sálica Emendata de 802 d.C.

O direito medieval feudal (séc. VIII ao XI) também foi compilado por escrito. Entre os registros desta época temos Usos de Barcelona (1068), a Carta de Pisa (1142) e os Libri Feudorum de Milão (1095).

O período da Alta Idade Média, ressaltamos, foi um dos mais arbitrários de toda a história do direito. A pena, no âmbito criminal, era usada para acomodar, segundo os interesses da nobreza da época, as situações desagradáveis aos detentores do poder, além de forçar os servos a realizarem condutas interessantes a quem ocupava o poder.

Alguns autores acreditam que a ignorância sobre a ilicitude da conduta pode ter sido considerada uma circunstância atenuante durante a Alta Idade Média. ${ }^{64}$

A Baixa Idade Média, por sua vez, significou o retorno da produção do direito baseado no estudo do direito romano, especialmente do Corpus iuris civilis, a codificação feita por Justiniano no século VI.

A passagem da Alta para a Baixa Idade Média além de ter sido marcada por uma grande manifestação intelectual e pelo resgate do direito romano, também é delineada pelo desenvolvimento do comércio, da retomada das rotas comerciais e a formação da burguesia.

Temos, portanto, um período caracterizado pelo desenvolvimento político e intelectual, esse último emergindo da experiência universitária dos centros de estudo dedicados à época em recuperar a cultura antiga e formular racionalmente suas inquietudes.

Em Bolonha, Paris, Salerno, Montpellier, por exemplo, começa a ser aplicado um novo método, o escolástico, cujo caráter preliminar é o lógico.

Assim, em 1100, consolida-se a Escola dos Glosadores, fundada por Irinério, padre que encontra na Universidade de Bolonha o Digesto de Justiniano. Esta escola durou entre os séculos XI e XIII e recebeu o nome de Glosadores por adotar um método de anotações em glosas (às margens e às linhas).

Em 1089 surge o gérmen dessa escola que se consolida em 1100 em razão de Inrinério ter fundado uma escola retórica que serviu como base da futura

\footnotetext{
${ }^{64}$ DUARTE, Caetano. O erro no código penal. Lisboa: Veja, 1984, p. 22.
} 
Universidade de Bolonha, naquela cidade. Irinério ensinava retórica a partir do método trivium, composto por três elementos: a gramática, a retórica e a dialética. Para aplicá-lo concretamente utilizou-se o Digesto romano. A partir de então o direito romano voltou a ser estudado e surgiu o que atualmente chamamos dogmática jurídica ${ }^{65}$. Segundo Tércio Sampaio Ferraz Jr.,

\begin{abstract}
A ciência européia do Direito propriamente dita nasceu em Bolonha no século XI. Com um caráter novo, mas sem abandonar o pensamento prudencial dos romanos, ela introduz uma nota diferente no pensamento jurídico: sua dogmaticidade. O pensamento dogmático, em sentido estrito, pode ser localizado nas suas origens neste período. Seu desenvolvimento foi possível graças a uma resenha crítica dos digestos justinianeus (Littera Boloniensis), os quais foram tranformados em textos escolares do ensino na universidade. Aceitos como base indiscutível do Direito, tais textos foram submetidos a uma técnica de análise que provinha das técnicas explicativas, usadas em sala de aula, sobretudo no Trivium - Gramática, Retórica e Dialética - caracterizando-se pela glosa gramatical e filosófica. ${ }^{66}$
\end{abstract}

A escola é chamada de Glosadores porque eram feitas às margens, e entre as linhas, os comentários sobre o desenvolvimento do método trivium. Essas anotações foram então chamadas de glosas marginais e interlineares.

O comentário de um capítulo inteiro do Digesto, segundo esse método, era chamado Summa e mais famosa delas foi a escrita por Azo. Segundo Pablo Koschaker, "la suma del codex hecho por el glosador Azo, exposición sistemática del código, distribuida en nueve libros, gozo de gran predicamento en la práctica jurídica del siglo XVII" ${ }^{67}$.

Ao final da escola dos Glosadores, seus escritos foram reunidos em uma das melhores Summas existentes, a Glosa ordinaria cujo autor foi Accursio. ${ }^{68}$

Os Glosadores não se preocupavam com uma aplicação prática do direito romano. Seu interesse era desenvolver o estudo da retórica. Era uma escola que considerava o direito romano uma revelação de Deus. Acreditavam que Ele tinha presenteado o teólogo com a bíblia e o jurista com aquele direito.

\footnotetext{
${ }^{65}$ BRANDÃO, Cláudio. Direito no pensamento jurídico medieval. In: BRANDÃO, Cláudio; SALDANHA, Nelson; FREITAS; Ricardo. História do direito e do pensamento jurídico em perspectiva. São Paulo: Atlas, 2012, p. 140.

${ }^{66}$ FERRAZ JÚNIOR, Tércio Sampaio. Função social da dogmática jurídica. São Paulo: Max Limonad, 1998, p. 36-37.

${ }^{67}$ KOSCHACKER, Pablo. Europa y el derecho romano. Madrid: Revista de directo privado, 1955, p. 137.

${ }^{68}$ KOSCHACKER, Pablo. Europa y el derecho romano. Madrid: Revista de directo privado, 1955, p. 138-139.
} 
A partir da análise do Corpus Juris Civilis, os Glosadores criaram um método jurídico completamente diferente do romano, na medida em que afastaram a importância da análise do caso concreto.

Assim, utilizaram o Corpus para desenvolver o estudo da retórica. A partir desta concepção, estava lançada a base fundamental para identificar o erro de direito a partir da ignorância da lei. O resultado foi uma grande confusão entre a consciência de ilicitude e a validade da lei, em face daqueles que a ignoram. Surge aí o fundamento ao princípio da inescusabilidade da ignorância da lei penal, que passou a ser um princípio absoluto da organização social.

Duas considerações julgamos importantes para entender o problema do conhecimento de lei durante o período da Baixa Idade Média. A primeira é o reforço da distinção, que vigorou entre os romanos, quanto à escusabilidade do erro de direito face à natureza da lei. Assim, a lei natural era inescusável (por ser indesculpável), enquanto a lei positiva escusava sempre que fosse desculpável. A segunda decorre da primeira e surge da influência que o direito canônico exerceu sobre o pensamento jurídico. Assim, todo o erro desculpável exclui a culpa do agente pelo seu comportamento. ${ }^{69}$

Ao fazer alusão ao direito intermediário, afirma Munhoz Netto que a ignorância de antijuridicidade, neste período, inspirou-se no direito romano e no direito canônico. Havia a presunção do conhecimento de lei quando se tratasse do direito natural e divino. Todavia, no direito civil prevaleciam as exceções do direito romano quanto às mulheres, escravos, menores, soldados e rústicos. ${ }^{70}$

A análise conjunta do direito canônico com o direito romano foi realizada pela escola dos Comentaristas, que sucedeu os Glosadores. Para Carlo Augusto Cannata, a nomenclatura pós-Glosadores não é aceitável pois não foram os Comentaristas que continuaram os estudos desenvolvidos pelos Glosadores. ${ }^{71}$

Ademais, os Glosadores somente conheciam o direito romano, enquanto os Comentaristas, mesmo julgando o direito romano como o mais importante na elaboração de um sistema jurídico, estimavam necessário considerar outras fontes, como o costume e o direito canônico. ${ }^{72}$

\footnotetext{
${ }^{69}$ DIAS, Jorge de Figueiredo. O problema da consciência da ilicitude em direito penal. Coimbra: Coimbra, 2000, p. 38-40.

${ }^{70}$ MUNHOZ NETTO, Alcides. A ignorância da antijuridicidade em matéria penal. Rio de Janeiro: Forense, 1978, p. 38-39.

${ }^{71}$ CANNATA, Carlo Augusto. Historia de la ciencia jurídica europea. Madrid: Editorial Tecnos, 1996, p. 147.

${ }^{72}$ KOSCHACKER, Pablo. Europa y el derecho romano. Madrid: Revista de directo privado, 1955, p. 144.
} 
A escola dos Comentaristas só pode ser compreendida à luz de um conhecimento prévio: a formação do Direito Canônico, correspondente ao ordenamento jurídico da Igreja católica, ou seja, "ao conjunto de fatores que estruturam a Igreja como uma sociedade juridicamente organizada",73. Nas palavras de Giudice:

\begin{abstract}
A igreja constitui uma única realidade composta por um elemento divino e por um elemento humano, correlativamente o Direito Canônico compõem-se de normas de origem divina, o direito divino (a exemplo, a revelação), as quais são tidas como absolutamente não derrogáveis por lei humano, civil ou eclesiásticas e normas de direito humano que surgem, por sua vez, da vontade da autoridade da Igreja para o governo da comunidade de fieis tais como o pontífice e o concílio ecumênico ${ }^{74}$
\end{abstract}

Em 1215, Graciano utiliza-se do método trivium para interpretar os cânones da igreja. Cânon vem da raiz grega que significa norma; os cânones eram, pois, as normas eclesiásticas. $\mathrm{O}$ trabalho de Graciano foi duplo: inicialmente, coube a ele separar os cânones verdadeiros dos falsos; em seguida, interpretar os cânones verdadeiros conforme a gramática, a retórica e a dialética. Assim, cria Graciano a famosa obra Concordia Discordantum Canonum.

O conjunto de normas emanadas pelo poder pontifício, sobretudo no século XII, formou o direito penal canônico, decisivo na prática da justiça punitiva, especialmente porque as decisões eclesiásticas recebiam execução pelos tribunais civis. $\mathrm{Na}$ medida em que crescia o poder da Igreja, as normas eclesiásticas se tornaram obrigatórias entre os eclesiásticos e os profanos e teve seu momento de sedimentação no século XIV, com a edição do Corpus júris canonici, que compreendia o Deretum Gratiani, editado no século XII, as Decretais de Gregório IX e Bonifácio VIII, as Clementinas, de Clemente V, e as Extravagantes ${ }^{75}$.

Os Comentaristas nutriam a mesma veneração dos Glosadores ao Direito Romano, considerando uma revelação divina, mas ao contrário destes, não queriam utilizá-lo para o estudo, unicamente, da retórica mas buscavam solucionar conflitos. Por isso, além da denominação escola dos Comentaristas ou Pós-Glosadores, há quem defina o período como escola dos Práticos. ${ }^{76}$

\footnotetext{
${ }^{73}$ LOMBARDÍA, Pedro. Lições de Direito Canônico. São Paulo: Edições Loyola, 2008, p. 15.

${ }^{74}$ GIUDICE, Federico del. Dizionario di Storia del Diritto Medievale e Moderno. Napoli: Edizioni Simone, 2010, p. 118.

${ }^{75}$ BRUNO, Aníbal. Direito Penal: parte geral. Tomo 1. Rio de Janeiro: Forense, 1978, p. 85-86.

${ }^{76}$ BRUNO, Aníbal. Direito Penal: parte geral. Tomo 1. Rio de Janeiro: Forense, 1978, p. 87.
} 
Para alcançar esse intento foi necessário unir o Direito Romano, de uma época distinta, a um Direito "vivo" daquele período concreto, chamado Direito Comum (ius comune). O ius comune, portanto, era produto da reunião do Direito Romano com o Direito Canônico.

O direito comum é um fenômeno jurídico que se coloca ao centro da história europeia do direito, designando o direito romano do período de Justiniano e as interpretações entre os séculos XII - XVIII, pela doutrina e jurisprudência da Europa ocidental.

No início do Direito Canônico, prevaleceu o princípio da irrelevância do desconhecimento sobre a lei, que, no máximo, poderia ter uma eficácia atenuante. Todavia, com Graciano, distingue-se entre a ignorantia iuris naturalis e a ignorantia iuris civilis. Segundo Munhoz Netto, "A ignorância de direito natural prejudicaria a todos os adultos mas, na "Summa Coloniensis", exclui-se expressamente a obrigação de conhecimento da lei os jovens, os surdos, os mudos, e os enfermos da mente."77

No transcurso do tempo, o Direito Canônico atenuou o rigor do princípio error vel ignorantia non excusat, atribuindo eficácia à ignorância das normas locais emanadas dos bispos. Assim, quem desconhecesse a lei eclesiástica não era penalmente responsável. Dever-se-ia, entretanto, observar se a ignorância era decorrente de negligência grosseira, quando, neste caso, a escusabilidade iria depender da complexidade da norma. Isto é, se houvesse necessidade de um efetivo conhecimento jurídico da norma, permanecia o caráter escusável do desconhecimento da lei. ${ }^{78}$

Entretanto, o caráter escusável do desconhecimento da lei estava restrito às leis de natureza civil, pois era recorrente a afirmação no Direito Comum de que todos deveriam conhecer as leis divinas, aquelas oriundas do Direito Natural. ${ }^{79}$

Destacamos também que já na Magna Charta $^{80}$ de João Sem Terra se faz referência à culpabilidade positivada, ao tratar da culpabilidade como uma medida para aplicar a pena. Segundo Willis Santiago Guerra Filho,

\footnotetext{
${ }^{77}$ MUNHOZ NETTO, Alcides. A ignorância da antijuridicidade em matéria penal. Rio de Janeiro: Forense, 1978 , p. 36.

${ }^{78}$ MUNHOZ NETTO, Alcides. A ignorância da antijuridicidade em matéria penal. Rio de Janeiro: Forense, 1978, p. 36-37.

${ }^{79}$ No Direito Estatutário Intermédio foram a ignorância e o erro de direito diversamente valorados conforme as diferentes leis imperantes. Afirmava-se que todo o mundo devia conhecer o Direito Natural e Divino e por isso ignorantiam júris naturalis meminem excusat (...) etiam si sit paganus vel homo silvester semper in montanis nutrius, ita quod nunquam ad eum predicatio pervenerit, nam in omnem terram exivit sonus Apostolorum". (DUARTE, Caetano. O erro no código penal. Lisboa: Veja, 1984, p. 22)

${ }^{80}$ A Magna Charta “(...) é uma expressão de um acordo do rei com os senhores, bispos e homens livres. Náo se trata de uma 'lei', uma 'constituição' ou uma 'declaração', mas de um documento que firma um acordo sobre os limites da jurisdição do rei, com as resalvas à autonomia dos diversos corpos. Note que no Prólogo, a saudação é dirigida aos
} 


\begin{abstract}
Um marco histórico para o surgimento desse tipo de formação política costuma-se apontar na Magna Charta inglesa, de 1215, na qual aparece com toda clareza manifestada a idéia acima referida, quando estabelece: "o homem livre não deve ser punido por um delito menor, senão na medida desse delito, e por um grave delito ele deve ser punido de acordo com a gravidade do delito." 81
\end{abstract}

Apesar da grande influência do direito penal entre os povos da região que, no século XIX, formaria a Itália, verificamos também, entre os germânicos, ter havido a recepção do direito romano, reelaborado pelos Glosadores e Comentaristas, inclusive, com influxo na legislação, em particular, na Constituição bamberguense e na Constitucio Criminalis Carolina, de $1532 .^{82}$

\title{
5. A culpabilidade no direito germânico: da responsabilidade penal objetiva à Constitucio Criminalis Carolina, como condição para a formação da dogmática penal
}

O direito germânico é essencialmente consuetudinário, de tradição oral e ligado à vida do grupo germânico. As normas jurídicas eram formuladas pela atuação do poder público e o povo que, reunidos em assembleia, batiam as lanças sobre os escudos (percussio armorum) em sinal de aprovação ${ }^{83}$.

O direito germânico tem importância singular para a formação e o desenvolvimento da dogmática penal, no século XIX, pelos alemães.

Pretendemos, portanto, analisar as bases da dogmática penal moderna a partir da culpabilidade entre os germânicos.

Sobre a importância da culpabilidade, desde os primórdios do direito germânico, Karl Binding afasta um entendimento recorrente, nos dias atuais, que aponta a responsabilidade penal, entre os romanos e os germânicos antigos, formada exclusivamente pelo resultado objetivo e sem a análise da vontade do agente. ${ }^{84}$ Observamos que, seguramente, não havia qualquer responsabilidade criminosa a

\footnotetext{
detentores de cargos ou estados (status) no reino e não a todos os habitantes ou pessoas. Só no curso da Revolução inglesa do século XVII é que este documento será tratado como um documento constitucional no sentido moderno do termo, sobretudo pelo esforço do jurista Edward Coke. Note também que existem várias edições da Magna Carta: a primeira é de 1215. Logo depois de assinada, o próprio rei pediu sua anulação, concedida pelo papa. O Rei João enfrentou, porém verdadeira guerra civil, e seus sucessores confirmaram o documento em 1216, 1217 e 1225, quando passou a ser chamada definitivamente de Magna Carta (The Great Charter). A versão firmada em 1225 fora expurgada de algumas cláusulas feudais.” (LOPES, José Reinaldo de Lima; QUEIROZ, Rafael Mafei Rabelo; ACCA, Thiago dos Santos. Curso de história do direito. São Paulo: Método, 2006, p. 30)

${ }^{81}$ GUERRA FILHO, Willis Santiago. Teoria processual da constituição. São Paulo: RCS, 2007, p. 57-58.

${ }^{82}$ BRUNO, Aníbal. Direito Penal: parte geral. Tomo 1.Rio de Janeiro, Forense, 1978, p. 88.

${ }^{83}$ GIUDICE, Federico del. Dizionario di Storia del Diritto Medievale e Moderno. Napoli: Edizioni Simone, 2010, p 119-120.

${ }^{84}$ BINDING, Karl. La culpabilidad en derecho penal. Montevideo-Buenos Aires: BdeF, 2009, p. 12-13.
} 
eventos resultantes de caso fortuito, entre os romanos (casus) e entre os germânicos antigos (Ungefährwerk) ${ }^{85}$.

Em sentido contrário, afirma Nilo Batista que a responsabilidade entre os germânicos antigos além de ser objetiva, era também grupal. ${ }^{86}$ Para o autor,

\begin{abstract}
Pouca ou nenhuma atenção, portanto, se dirige às condições pessoais do autor da ofensa; imputabilidade, controle consciente sobre sua execução, motivação e finalidades configuram, perante as relações fato-fridr ou fatoewa, simples antecedentes desprovidos de maior significado. Decorre daí o objetivismo das práticas penais germânicas antigas, sua contribuição para aquilo que se designaria por responsabilidade objetiva: o resultado, não a conduta e seus predicados, banaliza a reação penal. ${ }^{87}$
\end{abstract}

Todavia, Binding sustenta a tese sobre a responsabilidade subjetiva do agente ao afirmar que,

\begin{abstract}
Y como la voluntad en el crimen entre los germanos no se agotaba en querer el resultado causal, claramente representado, se infiere de ello, con plena fuerza probatoria, que el autor que invocaba un error, afirmando que no le permitió reconocer el hecho como crimen, era admitido, con base en esa mera afirmación, al juramento de purificación y quedaba libre cuando lo prestaba con validez formal.

Por tanto, la 'voluntad' era acompañada, de manera conceptualmente necesaria, del conocimiento de que el hecho era un delito. ${ }^{88}$
\end{abstract}

Enquanto os pós-glosadores se debruçaram no estudo da culpabilidade, os germanos, inicialmente, ficaram à margem da discussão. Para os germânicos, a imprudência integrava a categoria de quase delito, ideia que permaneceu até o final do século XVIII. Com a edição da Constitucio Criminalis Carolina (1532) é que o delito de imprudência se incorporou e manteve-se no Direito comum alemão, entretanto, limitando-se a poucos crimes, como, por exemplo, o homicídio. Apenas no século XIX é que a imprudência passou a ser tratada como causa de atenuação para o delito ordinário, influenciada pela jurisprudência italiana. ${ }^{89}$

\footnotetext{
${ }^{85}$ Segundo nota do tradutor, Manuel Cancio Meliá, "en la lengua alemana de la actualidad, la palabra ungefähr se mantiene en algunas expresiones (arcaizantes) que se refieren a fenómenos casuales, imprevisibles (del mismo modo que existe en castellano un uso residual de la palabra caso) [N. del T.]." (BINDING, Karl. La culpabilidad en derecho penal. Montevideo-Buenos Aires: BdeF, 2009, p. 12).

${ }^{86}$ BATISTA, Nilo. Matrizes Ibéricas do sistema penal brasileiro - I. Rio de Janeiro: Freitas Bastos, 2000, p. 4041.

${ }^{87}$ BATISTA, Nilo. Matrizes Ibéricas do sistema penal brasileiro - I. Rio de Janeiro: Freitas Bastos, 2000, p. 4041.

${ }^{88}$ BINDING, Karl. La culpabilidad en derecho penal. Montevideo-Buenos Aires: BdeF, 2009, p.13.

${ }^{89}$ BINDING, Karl. La culpabilidad en derecho penal. Montevideo-Buenos Aires: BdeF, 2009, p.18.
} 
Assim, apenas atuava com dolus malus e geverlich aquele cuja vontade estivesse dirigida à antijuridicidade concreta, reconhecida como tal pelo autor do fato. ${ }^{90}$

No decurso do século XIX, mais precisamente na década de 40, é que o vocábulo schuld (culpabilidade) passou a ser utilizado para designar a imputação (imputatio) pela prática de um crime. A culpabilidade começou então a ser desenvolvida pela dogmática penal alemã nascente, em especial, a partir das contribuições de Karl Binding, seguido pelos estudos de Franz von Liszt e Reinhard Frank.

\section{CONCLUSÃO}

Nas sociedades primitivas, a aplicação da pena estava associada à violação de um tabu, palavra de origem polinésica que significa a um só tempo o sagrado e o proibido. O direito era ainda fortemente impregnado pela religião. A distinção entre regra religiosa e regra jurídica é muitas vezes difícil, porque o homem vive constantemente influenciado pelos poderes sobrenaturais. Estas sociedades são caracterizadas pelo que chamamos "indiferenciação", ou seja, as diversas funções sociais que distinguimos nas sociedades modernas, como a religião, a moral e o direito, estão aí confundidas

A culpabilidade não importava para a responsabilização do agente que pertencia a um grupo primitivo. Isto, porque, realizado o fato danoso, o indivíduo era responsabilizado, independentemente da vontade de praticar o evento.

Entre os povos da antiguidade oriental, a culpabilidade também era desconhecida, pois a responsabilidade penal era objetiva e, por vezes, coletiva. Também, deve-se registrar que apesar do grande avanço que os gregos trouxeram à política e ao direito, também não verificamos entre eles o tratamento da culpabilidade. É com os romanos, por sua vez, que a intenção do sujeito começa a ter um caráter decisivo para a responsabilidade penal, derivado, certamente do conceito de culpabilidade que surgia.

São inúmeras as contribuições ao direito, especialmente o direito penal, advindas dos romanos. Entre eles, citemos o desenvolvimento da doutrina da imputabilidade, da culpabilidade e suas excludentes. Também os romanos desenvolveram institutos como o do nexo de causalidade, dolo, imprudência, caso

\footnotetext{
${ }^{90}$ BINDING, Karl. La culpabilidad en derecho penal. Montevideo-Buenos Aires: BdeF, 2009, p.23. Em lugar do termo malus, o Código Penal bávaro de 1813 (Feuerbach), introduziu a palavra antijurídico, ou seja, dolo antijurídico.
} 
fortuito. Cumpre destacar que foram também os primeiros a abordar a doutrina do erro por meio da dicotomia error facti-error ius cujo legado foi a ideia de dolus malus, indispensável para a análise do erro em direito penal, nesse período histórico.

Imprescindível para entendermos a formação da culpabilidade entre os romanos é o estudo do dolus malus. A unidade da culpabilidade (intenção atrelada ao mau propósito, ou dolus malus) é superada pelos romanos ao descobrirem sua segunda forma, qual seja, a culpa stricto sensu. Assim, havia o dolus malus e a imprudência entre os romanos.

O princípio da inescusabilidade do desconhecimento de lei foi uma criação do direito romano, estudado a partir da dicotomia erro de fato-erro de direito, que atribui a escusabilidade à primeira modalidade de erro e a não escusabilidade para a segunda. Todavia, a doutrina não é pacífica quanto ao caráter de inescusabilidade em decorrência do erro de direito, entre os romanos. Quanto à ignorância da lei, foi aplicada ao direito penal romano uma regra de direito privado: a presunção do conhecimento das leis do Estado por todos os indivíduos. Logo, em Roma, vigorou o princípio error jus nocet. Entretanto destacamos que o princípio error jus nocet não era absoluto, ou seja, admitia exceção.

Todavia, cumpre destacar que toda sistematização empreendida atualmente pelos estudiosos sobre o direito romano é fruto do pensamento da modernidade, tendo em vista que os romanos aplicaram o direito por meio da retórica e da dialética e não a partir de conceitos ou classificações abstratas, como se tenta atribuí-los.

Certamente, uma má interpretação do erro de direito sob o prisma da estabilidade, provavelmente levou os autores modernos (positivistas), ao recepcionarem a dicotomia error facti-error ius, atribuírem ao erro de direito o seu caráter inescusável.

Entendemos assim que as regras error iuris nocet e error facti non nocet pretenderem estabelecer uma presunção de prova, que comportava exclusões. Não poderia haver no direito romano uma presunção absoluta a partir da aplicação do direito no caso concreto.

O direito medieval ocidental é marcado por um vasto período e diferentes enfoques. É possível, por sua vez, fazermos um corte epistemológico e estruturarmos a Idade Média em dois grandes períodos: a Alta Idade Média, marcada pelo feudalismo, e a Baixa Idade Média, que compreende o poder temporal da Igreja.

A produção do direito, durante a Alta Idade Média, é pouquíssima quando comparada ao direito romano. Esse período foi um dos mais arbitrários de toda a 
história do direito. A pena, no âmbito criminal, era usada para acomodar, segundo os interesses da nobreza da época, as situações desagradáveis aos detentores do poder, além de forçar os servos a realizarem condutas interessantes a quem ocupava o poder.

Acredita-se que a ignorância sobre a ilicitude da conduta pode ter sido considerada uma circunstância atenuante durante a Alta Idade Média.

A passagem da Alta para a Baixa Idade Média além de ter sido marcada por uma grande manifestação intelectual e pelo resgate do direito romano, também é delineada pelo desenvolvimento do comércio, da retomada das rotas comerciais e a formação da burguesia. Em 1089 surge o gérmen dessa escola que se consolida em 1100 em razão de Inrinério ter fundado uma escola retórica que serviu como base da futura Universidade de Bolonha, naquela cidade. Irinério ensinava retórica a partir do método trivium, composto por três elementos: a gramática, a retórica e a dialética. Para aplicá-lo concretamente utilizou-se o Digesto romano. A partir de então o direito romano voltou a ser estudado e surgiu o que atualmente chamamos dogmática jurídica.

Duas considerações julgamos importantes para entender o problema do conhecimento de lei durante o período da Baixa Idade Média. A primeira é o reforço da distinção, que vigorou entre os romanos, quanto à escusabilidade do erro de direito face à natureza da lei. Assim, a lei natural era inescusável (por ser indesculpável), enquanto a lei positiva escusava sempre que fosse desculpável. A segunda decorre da primeira e surge da influência que o direito canônico exerceu sobre o pensamento jurídico. Assim, todo o erro desculpável exclui a culpa do agente pelo seu comportamento.

No transcurso do tempo, o Direito Canônico atenuou o rigor do princípio error vel ignorantia non excusat, atribuindo eficácia à ignorância das normas locais emanadas dos bispos. Assim, quem desconhecesse a lei eclesiástica não era penalmente responsável. Dever-se-ia, entretanto, observar se a ignorância era decorrente de negligência grosseira, quando, neste caso, a escusabilidade iria depender da complexidade da norma. Isto é, se houvesse necessidade de um efetivo conhecimento jurídico da norma, permanecia o caráter escusável do desconhecimento da lei.

Entretanto, o caráter escusável do desconhecimento da lei estava restrito às leis de natureza civil, pois era recorrente a afirmação no Direito Comum de que todos deveriam conhecer as leis divinas, aquelas oriundas do Direito Natural.

Enquanto os pós-glosadores (Baixa Idade Média) se debruçaram no estudo da culpabilidade, os germanos, inicialmente, ficaram à margem da discussão. Para os germânicos, a imprudência integrava a categoria de quase delito, ideia que permaneceu 
até o final do século XVIII. Com a edição da Constitucio Criminalis Carolina (1532) é que o delito de imprudência se incorporou e manteve-se no Direito comum alemão, entretanto, limitando-se a poucos crimes, como, por exemplo, o homicídio. Apenas no século XIX é que a imprudência passou a ser tratada como causa de atenuação para o delito ordinário, influenciada pela jurisprudência italiana.

Assim, apenas atuava com dolus malus e geverlich aquele cuja vontade estivesse dirigida à antijuridicidade concreta, reconhecida como tal pelo autor do fato. ${ }^{91}$

No decurso do século XIX, mais precisamente na década de 40, é que o vocábulo schuld (culpabilidade) passou a ser utilizado para designar a imputação (imputatio) pela prática de um crime. A culpabilidade começou então a ser desenvolvida pela dogmática penal alemã nascente, em especial, a partir das contribuições de Karl Binding, seguido pelos estudos de Franz von Liszt e Reinhard Frank.

\section{REFERÊNCIAS}

ADEODATO, João Maurício. Ética e retórica: para uma teoria da dogmática jurídica. São Paulo: Saraiva, 2002.

AFTALIÓN, Enrique R.; VILANOVA, José. Introduccion al derecho. Buenos Aires: Abeledo-Perrot, 1994.

ALVES, José Carlos Moreira Alves. Direito Romano, vol. I. Rio de Janeiro: Forense, 2004.

ALVES, Marcelo. Antígona e o direito. Curitiba: Juruá, 2007.

BATISTA, Nilo. Matrizes Ibéricas do sistema penal brasileiro - I. Rio de Janeiro: Freitas Bastos, 2000.

BINDING, Karl. La culpabilidad en derecho penal. Montevideo-Buenos Aires: BdeF, 2009.

BRANDÃO, Cláudio. Introdução ao direito penal: análise do sistema penal à luz do princípio da legalidade. Rio de Janeiro: Forense, 2002.

Culpabilidade: sua análise na dogmática e no direito penal brasileiro. Revista portuguesa de ciência criminal. Coimbra, Coimbra, Ano 15, n.2, 2005.

\footnotetext{
${ }^{91}$ BINDING, Karl. La culpabilidad en derecho penal. Montevideo-Buenos Aires: BdeF, 2009, p.23. Em lugar do termo malus, o Código Penal bávaro de 1813 (Feuerbach), introduziu a palavra antijurídico, ou seja, dolo antijurídico.
} 
Erro de proibição: uma análise da sua relevância para a exclusão da culpabilidade. Recife: Dissertação de mestrado em direito da UFPE, 1998.

BRANDÃO, Cláudio. O direito grego clássico. In: BRANDÃO, Cláudio; SALDANHA, Nelson; FREITAS; Ricardo. História do direito e do pensamento jurídico em perspectiva. São Paulo: Atlas, 2012.

BRUNO, Aníbal. Direito Penal: parte geral. tomo $1^{\circ}$. Rio de Janeiro, Forense, 1978.

CANNATA, Carlo Augusto. Historia de la ciencia jurídica europea. Madrid: Editorial Tecnos, 1996.

Corpus Iuris Civilis, Cuerpo del Derecho Civil Romano, traduzido do original alemão publicado por KRIEGEL, HERMANN e OSENBRÜGGEN, ao espanhol por D. Ildefonso L. García del Corral. Barcelona: Jaime Molinas, 1889.

COULANGES, Fustel de. A cidade antiga. São Paulo: Martins Fontes, 2004.

DIAS, Jorge de Figueiredo. O problema da consciência da ilicitude em direito penal. Coimbra: Coimbra, 2000.

DUARTE, Caetano. O erro no código penal. Lisboa: Veja, 1984.

FERRAZ JÚNIOR, Tércio Sampaio. Função social da dogmática jurídica. São Paulo: Max Limonad, 1998.

GILISSEN, John. Introdução Histórica ao Direito. Lisboa: Fundação Calouste Gulbenkian, 1986.

GIUDICE, Federico del. Dizionario di Storia del Diritto Medievale e Moderno. Napoli: Edizioni Simone, 2010.

GONZAGA, Álvaro de Azevedo; FLORÊNCIO FILHO, Marco Aurélio. O Diálogo entre um filósofo e um jurista - considerações sobre o livro IX - o direito criminal - na obra As Leis de Platão. In: ZOVICO, Marcelo Roland, (Org.). Filosofia do direito: Estudos em Homenagem a Willis Santiago Guerra Filho. São Paulo: Clássica, 2012, p. $32-42$.

GUERRA FILHO, Willis Santiago. Teoria processual da constituição. São Paulo: RCS, 2007.

GUERRA FILHO. Willis Santiago; CARNIO, Henrique Garbellini. Teoria da ciência jurídica. São Paulo: Saraiva, 2009.

HERRERA, Lucio Eduardo. El error en materia penal. Buenos Aires: Abeledo-Perrot, 1971.

JIMÉNEZ DE ASÚA, Luis. Tratado de derecho penal: concepto del derecho penal y de la criminología, historia y legislación penal comparada. Tomo 1.Buenos Aires: Losada, 1950. 
KOSCHACKER, Pablo. Europa y el derecho romano. Madrid: Revista de directo privado, 1955.

LISZT, Franz von La idea del fin en el derecho penal. Granada: Comares, 1995.

LOMBARDÍA, Pedro. Lições de Direito Canônico. São Paulo: Edições Loyola, 2008.

LOPES, José Reinaldo de Lima. O Direito na História. São Paulo: Atlas, 2008.

LOPES, José Reinaldo de Lima; QUEIROZ, Rafael Mafei Rabelo; ACCA, Thiago dos Santos. Curso de história do direito. São Paulo: Método, 2006.

LUNA, Everardo da Cunha. Estrutura jurídica do crime e outros estudos. Recife: Unversidade Federal de Pernambuco, 1970.

MACHADO, Fábio Guedes de Paula. A culpabilidade no direito penal contemporâneo. São Paulo: Quartier Latin, 2010.

MOMMSEN, Teodoro. Derecho penal romano. Bogotá: Editorial Temis S.A., 1999.

MUNHOZ NETTO, Alcides. A ignorância da antijuridicidade em matéria penal. Rio de Janeiro: Forense, 1978.

PINTO, Cristiano Paixão Araújo. Direito na Sociedade no Oriente Antigo: Mesopotâmia e Egito. In: WOLKMER, Antonio Carlos. Fundamentos de História do Direito. Belo Horizonte: Del Rey, 2008, p. 13-37.

PLATÃO. As leis, ou da legislação e Epinomis. São Paulo: Edipro, 1999.

PRADO, Luiz Regis. Curso de direito penal brasileiro: parte geral. São Paulo: RT, 2000.

SMANIO, Gianpaolo Poggio; FABRETTI, Humberto Barrionuevo. Introdução ao direito penal: criminologia, princípios e cidadania. São Paulo: Atlas, 2010.

SÓFOCLES. Antígona. Rio de Janeiro: Difel, 2001.

TRAPERO BARREALES, María A. El error en las causas de justificación. Valencia: Tirant lo Blanch, 2004.

VOCI, Paquale. L’errore nel direito romano. Milano: Dott. A. Giuffré, 1937.

WOLKMER, Antonio Carlos. O Direito nas Sociedades Primitivas In: WOLKMER, Antonio Carlos. Fundamentos de História do Direito. Belo Horizonte: Del Rey, 2008. 